\title{
Choosing a Right Surfactant for Respiratory Distress Syndrome Treatment
}

\author{
Rangasamy Ramanathan \\ Division of Neonatal Medicine, Department of Pediatrics, Women's and Children's Hospital and Children's Hospital \\ Los Angeles, Keck School of Medicine, University of Southern California, Los Angeles, Calif., USA
}

\section{Key Words}

Respiratory distress syndrome, right surfactant • Respiratory distress syndrome treatment $\cdot$ Synthetic surfactants $\cdot$ Natural, modified surfactants

\begin{abstract}
Respiratory distress syndrome (RDS) is the most common cause of respiratory insufficiency in preterm infants, especially those born at $<30$ weeks of gestation. Continuous positive airway pressure has been used since the 1970s as a primary mode of treatment for RDS. Surfactant therapy became available in the 1980s and has become the standard care for infants with or at risk for RDS. Surfactant therapy has been shown to decrease air leaks, neonatal and infant mortality as well as cost among survivors. Natural surfactants derived from animal sources containing surfactant proteins $B$ (SP-B) and $C$ (SP-C) as well as synthetic surfactants with functional SP-B- or SP-C-like protein mimics have been extensively evaluated in preterm neonates with or at risk for RDS. Evidence from randomized controlled trials indicates that treatment with natural surfactants results in faster weaning of supplemental oxygen and mean airway pressure, decreased duration of mechanical ventilation, and decreased mortality when compared to synthetic surfactants. Furthermore, at the present time, there are no approved synthetic surfactants available for use in preterm infants. Beractant, calfactant and poractant alfa are the three commonly used natural surfactants worldwide. Comparative studies including pro-
\end{abstract}

spective randomized trials as well as large retrospective studies have shown significant differences in outcome and cost among these three natural surfactants. Of the eight prospective, randomized controlled trials and two retrospective studies involving the natural surfactant preparations, treatment with poractant alfa resulted in a significantly decreased mortality, decreased need for additional doses, faster weaning of oxygen and reduced hospital costs when compared to treatment with beractant or calfactant. These differences in outcome may be due to differences in phospholipid and SP-B content, amount of antioxidant phospholipids, plasmalogens, anti-inflammatory properties and viscosity among these three surfactants. Additional studies of administering surfactant non-invasively via laryngeal mask airway in preterm infants weighing $>1,200 \mathrm{~g}$ and as an aerosol preparation are currently in progress.

Copyright $\odot 2008$ S. Karger AG, Basel

\section{Introduction}

Preterm births continue to increase in spite of major advances in perinatal care, especially in developed countries. In the USA, the preterm delivery rate is $12-13 \%$ and in Europe and other developed countries, reported rates

Presented at the International Symposium 'Recent Advances in Neonatal Medicine', Würzburg, 2008.

\section{KARGER}

Fax +41613061234 E-Mail karger@karger.ch www.karger.com
(C) 2008 S. Karger AG, Basel 1661-7800/09/0951-0001\$26.00/0

Accessible online at:

www.karger.com/neo
Prof. Rangasamy Ramanathan, MD

Division of Neonatal Medicine, Department of Pediatrics, Women's and Children's Hospital and Children's Hospital Los Angeles, Keck School of Medicine

University of Southern California, Los Angeles, CA 90033 (USA)

Tel. +1 323226 3409, Fax +1 323226 3440, E-Mail ramanath@usc.edu 
are generally between 5 and 9\% [1]. Prematurity is now the number one cause of infant mortality accounting for $34.3 \%$ of all infant deaths in 2002 [2]. Respiratory distress syndrome (RDS) occurs in nearly $50 \%$ of preterm infants born at $<30$ weeks of gestation [3]. Surfactant therapy has become the standard of care in preterm infants with RDS and is associated with a decrease in pneumothorax, and neonatal and infant mortality. The composition of surfactant is quite similar across a variety of mammalian species; however, it is a very complex, multifunctional material produced by type II alveolar epithelial cells, consisting of $\sim 90 \%$ lipids and $10 \%$ proteins by weight. Four surfactant proteins (SP) have been isolated to date and SP-B and SP-C act synergistically with the phospholipids to lower surface tension in the lung. The most important phospholipid in terms of physiologic function is dipalmitoylphosphatidylcholine (DPPC), which has the ability to lower surface tension at the air-liquid interphase and stabilize the alveoli during exhalation. The roles of other acidic phospholipids such as sphingomyelin, phosphatidylinositol, or phosphatidylethanolamine are not well known. Phosphatidylglycerol (PG), another important phospholipid, generally appears later in gestation and helps to lower surface tension.

Natural, modified surfactants containing SP-B and SP-C, derived from animal sources as well as synthetic surfactants containing a functional equivalent of SP-B or SP-C protein mimics have been extensively evaluated in preterm infants with or at risk for RDS.

\section{Synthetic Surfactants}

A number of synthetic surfactants (not containing SP$\mathrm{B}$ and SP-C) have been evaluated in the treatment of preterm infants with RDS. Fourteen comparative trials using different synthetic surfactants and natural, modified surfactant preparations have been published [4-17]. To date, treatment with natural surfactants has been shown to be associated with better response during the acute phase of RDS, and decreased mortality compared with synthetic surfactant preparations. However, the incidence of bronchopulmonary dysplasia (BPD) was not different between infants treated with synthetic and natural surfactants. In the only trial that compared two different synthetic preparations, namely colfosceril palmitate $\left(\right.$ Exosurf ${ }^{\circledR}$ ) and lucinactant $\left(\right.$ Surfaxin $\left.^{\circledR}\right)$, BPD was significantly lower ( 40.2 vs. $45 \%, \mathrm{p}=0.045$ ) with lucinactant [16]. However, a comparison of lucinactant with natural surfactants, beractant (Survanta ${ }^{\circledR}$ ) and poractant alfa (Curosurf ${ }^{\circledR}$ ) failed to show any significant differences in the occurrence of BPD $[16,17]$. Both these studies had methodological problems, and did not address the question of superiority of synthetic surfactant over natural surfactants [18]. The first trial [16] involving lucinactant had three groups of preterm infants randomized to receive lucinactant, colfosceril palmitate or beractant. Infants receiving lucinactant had less RDS and less BPD in this prophylaxis trial than those receiving colfosceril palmitate, but not less than those receiving beractant. The second trial [17] had two groups, comparing lucinactant with poractant alfa. No differences were found in the incidence of RDS, mortality or BPD between these two preparations. However, there were some major problems with these studies. The first trial [16] was underpowered to study the efficacy against beractant, and the second study [17] was designed as a 'non-inferiority' study. It was stopped due to slow recruitment of patients after enrolling only 252 of the original calculated sample size of 496 patients, and was also underpowered even to establish equivalency between lucinactant and poractant alfa. Furthermore, mortality data used to calculate the sample size was based on results of a treatment trial published in 1988, and this endpoint was chosen for regulatory approval reasons, rather than to truly compare synthetic versus natural surfactants [17]. The dose of poractant alfa used in this prophylaxis trial also was not the approved dose for poractant alfa. The American Academy of Pediatrics and the Committee of the Fetus and Newborn (COFN) recently issued a clinical report on the use of synthetic and natural surfactants. COFN members wrote the following statement in their report: 'More analysis is needed before the findings from lucinactant studies can be generalized because of questions about early trial closure and limited statistical power. Moreover, the metabolic fate of lucinactant and its component chemicals and potential risks introduced by the requirement to convert the lucinactant gel into liquid by using a special warming cradle immediately before instillation need additional study' [19].

\section{Natural, Modified Surfactants}

Natural, modified surfactants derived from bovine or porcine origin have been available for treatment of preterm infants with RDS for more than two decades. Natural surfactants available for clinical use differ in their composition, amount of phospholipids, surfactant-associated proteins, plasmalogens, viscosity and volume of 
administration. Among the three commonly studied natural surfactants, beractant, calfactant and poractant alfa, the lattermost contains the highest amount of phospholipids distributed in the lowest volume as well as the highest amount of plasmalogens. All surfactants have varying degrees of antibacterial properties against Gram-positive and Gram-negative pathogens. Pulmonary surfactant phospholipids have been shown to regulate inflammatory functions of human monocytes. Total phosphatidylcholine and DPPC content inhibit the release of proinflammatory cytokines, like tumor necrosis factor- $\alpha$ (TNF- $\alpha$ ) from human monocytic cell lines, exposed to lipopolysaccharide in a dose-dependent manner [20]. In vitro studies of beractant, which contains the lowest amount of SP-B among the three natural surfactant preparations, have shown that reconstitution of beractant with additional SP-B improved adsorption, dynamic surface tension-lowering and pressure-volume activity [21]. Spiking beractant with synthetic surfactant peptides B and $\mathrm{C}$ also improved oxygenation in surfactant deficient mice [22]. Finally, plasmalogens which are antioxidant phospholipids may offer protection against oxidative stress, especially in preterm infants with reduced antioxidant activity. Higher plasmalogen content in tracheal aspirate fluid at birth in preterm infants is associated with a decreased risk of BPD [23]. Plasmalogens also work synergistically with SP-B to adsorb DPPC and lower the surface tension. These characteristics may account for some of the differences seen in comparative trials using different natural surfactant preparations.

Ten studies have compared the three natural surfactants, eight [24-29] were randomized controlled trials and two were retrospective studies [30,31]. Four of the eight trials compared beractant with calfactant and the other four trials compared beractant with poractant alfa. One trial compared beractant and calfactant in the prophylactic treatment of RDS [24] and no differences in BPD or mortality were found. However, mortality in infants $<600$ g was significantly higher in the calfactanttreated group (63 vs. $26 \%$ ). A second study involving the same two surfactants in the treatment of RDS [24] again found no differences in BPD or death, and treatment with calfactant was associated with a lower average $\mathrm{FiO}_{2}$ and mean airway pressure during the first $72 \mathrm{~h}$ compared to beractant. Two large but incomplete trials involving a total of 2,110 preterm infants were published in 2005 [25]. Both these trials were stopped after 32 months due to slow recruitment. Inadequate sample sizes due to early trial closure prevented the investigators from accepting or rejecting null hypotheses. However, in the prophylax- is study with 749 patients, the proportion of infants alive with BPD was $34 \%$ in the beractant group and $33 \%$ in the calfactant group. Similarly, in the rescue trial, the proportion of infants alive with BPD was identical, at $31 \%$ in both beractant- and calfactant-treated infants. Speer et al. [26] compared beractant with poractant alfa in the treatment of RDS. Treatment with poractant alfa was associated with a significantly faster weaning of supplemental oxygen, peak inspiratory pressure and mean airway pressure during the first $24 \mathrm{~h}$ following treatment. No other differences were reported in this trial, although mortality, air leaks and severe grades of intraventricular hemorrhage were three to four times more frequent in the beractant-treated group. However, none of these findings was statistically significant likely due to small sample size. In a study comparing beractant with poractant alfa, Baroutis et al. [27] also included a third natural surfactant, namely SF-RI-1 (Alveofact ${ }^{\circledR}$ ), and used $100 \mathrm{mg} / \mathrm{kg} /$ dose for all three surfactants. Poractant-alfa-treated infants spent fewer days on oxygen and mechanical ventilation, and had a shorter length of stay when compared to those treated with beractant. Ramanathan et al. [28] performed a multicenter, randomized trial comparing 100 $\mathrm{mg} / \mathrm{kg} /$ dose of beractant with 100 or $200 \mathrm{mg} / \mathrm{kg}$ of poractant alfa for the first dose in the treatment of RDS. Additional doses if required were given at $100 \mathrm{mg} / \mathrm{kg}$ for both surfactant preparations. Treatment with $200 \mathrm{mg} / \mathrm{kg}$ initial dose of poractant alfa resulted in faster weaning of supplemental oxygen, and a significantly decreased number of additional doses when compared to beractant. Mortality at 36 weeks' postmenstrual age for infants born at $\leq 32$ weeks' gestational age was $3 \%$ in the $200-\mathrm{mg} / \mathrm{kg}$ poractant alfa group compared with $11 \%$ in the beractant-treated group $(p<0.034)$. In a meta-analysis of the results from Speer et al. and Ramanathan et al., mortality was significantly lower (odds ratio 0.35 , 95\% confidence interval 0.13-0.92) with poractant alfa [29]. Malloy et al. [30] compared the effects of poractant alfa and beractant on weaning of supplemental oxygen following treatment. They demonstrated significantly faster weaning of oxygen in the poractant-alfa-treated infants up to $48 \mathrm{~h}$ after the first dose when compared to beractant. As in the study by Ramanathan et al. [28], the poractantalfa-treated group required significantly fewer doses [30]. Higher initial doses used in these trials may have accounted for the decrease in redosing with poractant alfa.

Very few comparative economic analyses have been published using different surfactants. Gerdes et al. [31] in an open-label comparison of calfactant with poractant 
alfa showed cost benefits favoring poractant alfa. In a cost-minimization analysis comparing poractant alfa and beractant, Marsh et al. [32] reported significant cost savings with poractant alfa treatment compared to beractant. Randomized controlled trials comparing the three natural, modified surfactant preparations published between 1995 and 2005 show that treatment with poractant alfa is associated with faster weaning of oxygen, fewer additional doses, survival advantage and cost benefits when compared to beractant or calfactant [33]

Two large retrospective studies involving more than 30,000 infants have been reported. In a study by Clark et al. [34], there was no difference in mortality between beractant- and calfactant-treated infants in any birth weight group, in contrast to the results from a randomized controlled trial published by Bloom et al. [24] that showed a higher mortality in infants $<600 \mathrm{~g}$ treated with calfactant. Recently, Ramanathan et al. [35] reported results from a very large study involving 24,883 infants treated with beractant, calfactant or poractant alfa. This is the largest study reported to date involving preterm infants treated with one of the three surfactants commonly used in the USA. Adjusted all-cause mortality was significantly lower in the poractant-alfa-treated group compared to beractant or calfactant. This mortality difference persisted when the data were analyzed in preterm infants $\leq 34$ weeks' gestation. Mortality difference was independent of hospital type or year studied. Sekar et al. [36], reporting results from pharmacoeconomic analyses involving the same population, showed that treatment with poractant alfa was associated with significant cost benefits compared to beractant or calfactant.

In summary, treatment of preterm infants with or at risk for RDS with natural surfactants results in better clinical outcomes. At the time of this review, there are no synthetic surfactants available for use in preterm infants. Among the natural surfactants available worldwide, prospective as well as retrospective studies show that treatment with poractant alfa results in consistently better outcomes when compared to beractant or calfactant. Poractant alfa is also the only surfactant that shows a decreased mortality when compared with synthetic or natural surfactants. Poractant alfa may be the best choice for a natural, modified surfactant preparation based on results from clinical studies. Future efforts should be directed at developing a synthetic surfactant that is better than currently available natural, modified surfactants to eliminate the potential risks of infection, and potential antigenicity from bovine or porcine SP-B and SP-C. Attempts to deliver surfactant non-invasively via a laryngeal mask airway in relatively bigger preterm infants or using aerosol techniques are currently being studied.

\section{References}

1 Slattery MM, Morrison JJ: Preterm delivery. Lancet 2002;360:1489-1497.

2 Callaghan WM, MacDorman MF, Rasmussen SA, Qin C, Lackritz EM: The contribution of preterm birth to infant mortality in the United States. Pediatrics 2006;118:15661573.

- 3 Lemons JA, Bauer CR, Oh W, Korones S, Papile LA, Stoll BJ, Verter J, Temprosa M, Wright LL, Ehrenkranz RA, Fanaroff AA, Stark A, Carlo W, Tyson JE, Donovan EF, Shankaran S, Stevenson DK: Very low birth weight infant outcomes of the NICHD Neonatal Research Network, January 1995-December 1996. Pediatrics 2001;107:e1-e8.

-4 Horbar JD, Wright LL, Soll RF Wright EC, Fanaroff AA, Korones SB, Shankaran S, Oh W, Fletcher BD, Bauer CR: A multicenter randomized trial comparing two surfactants for the treatment of neonatal respiratory distress syndrome. National Institute of Child Health and Human Development Neonatal Research Network. J Pediatr 1993;123:757766.
5 Alvarado M, Hingre R, Hakason D, Gross S: Clinical trial of Survanta versus Exosurf in infants $<1,500 \mathrm{~g}$ with respiratory distress syndrome. Pediatr Res 1993;33:314A.

6 Pearlman SA, Leef KH, Stefano JL, Speer ML, Esterly KL: A randomized trial comparing Exosurf versus Survanta in the treatment of neonatal RDS. Pediatr Res 1993;33:340A.

7 Sehgal SS, Ewing CK, Richards T, Taeusch HW: Modified bovine surfactant (Survanta) versus a protein-free surfactant (Exosurf) in the treatment of respiratory distress syndrome in preterm infants: a pilot study. J Natl Med Assoc 1994;86:46-52.

8 Vermont-Oxford Neonatal Network: A multicenter, randomized trial comparing synthetic surfactant with modified bovine surfactant extract in the treatment of neonatal respiratory distress syndrome. Pediatrics 1996;97:1-6.
-9 Hudak ML, Farrell EE, Rosenberg AA, Jung $\mathrm{Al}$, Auten Rl, Durand DJ, Horgan MJ, Buckwald S, Belcastro MR, Donohue PK, Carrion V, Maniscalco WW, Balsan MJ, Torres BA, Miller RR, Jansen RD, Graeber JE, Laskay KM, Matteson EJ, Egan EA, Brody AS, Martin DJ, Riddlesberger MM, Montgomery P: A multicenter randomized, masked comparison trial of natural versus synthetic surfactant for the treatment of respiratory distress syndrome. J Pediatr 1996;128:396-406.

10 Hudak ML, Martin DJ, Egan EA, Matteson EJ, Cummings NJ, Jung AL, Kimberlin LV, Auten RL, Rosenberg AA, Asselin JM, Belcastro MR, Donohue PK, Hamm CR Jr, Jansen RD, Brody AS, Riddlesberger MM, Montgomery P: A multicenter randomized masked comparison trial of synthetic surfactant versus calf lung surfactant extract in the prevention of neonatal respiratory distress syndrome. Pediatrics 1997;100:39-50. 
11 Modanlou HD, Beharry K, Padilla G, Norris K, Safvati S, Aranda JV: Comparative efficacy of Exosurf and Survanta surfactants on early clinical course of respiratory distress syndrome and complications of prematurity. J Perinatol 1997;17:455-460.

12 Da Costa DE, Pai MG, Al Khusaiby SM: Comparative trial of artificial and natural surfactants in the treatment of respiratory distress syndrome of prematurity: experiences in a developing country. Pediatr Pulmonol 1999;27:312-317.

13 Rollins M, Jenkins J, Tubman R, Corkey C, Wilson D: Comparison of clinical responses to natural and synthetic surfactants. J Perinat Med 1993;21:341-347.

14 Kukkonen AK, Virtanen M, Jarvenpaa AL, Pokela ML, Ikonen S, Fellman V: Randomized trial comparing natural and synthetic surfactant: increased infection rate after natural surfactant? Acta Paediatr 2000;89:556561.

15 Ainsworth SB, Beresford MW, Milligan DW, Shawn NJ, Matthews JN, Fenton AC, Ward Platt MP: Pumactant and poractant alfa for treatment of respiratory distress syndrome in neonates born at 25-29 weeks' gestation: a randomised trial. Lancet 2000;355:13871392.

-16 Moya FR, Gadzinowski J, Bancalari E, Salinas V, Kopelman B, Bancalari A, Kornacka MK, Merritt TA, Segal R, Schaber CJ, Tsai H, Massaro J, d'Agostino R, International Surfaxin Collaborative Study Group: A multicenter, randomized, masked, comparison trial of lucinactant, colfosceril palmitate, and beractant for the prevention of respiratory distress syndrome among very preterm infants. Pediatrics 2005;115:1018-1029.

- 17 Sinha SK, Lacaze-Masmonteil T, Valls i Soler A, Wiswell TE, Gadzinowski J, Hajdu J, Bernstein G, Sanchez-Luna M, Segal R, Schaber CJ, Massaro J, d'Agostino R, Surfaxin Therapy Against Respiratory Distress Syndrome Collaborative Group: A multicenter, randomized, controlled trial of lucinactant versus poractant alfa among very premature infants at high risk for respiratory distress syndrome. Pediatrics 2005;115:1030-1038.
18 Kattwinkel J: Synthetic surfactants: the search goes on. Pediatrics 2005;115:10751076.

19 Engle WA and the Committee on Fetus and Newborn: Surfactant-replacement therapy for respiratory distress in the preterm and term neonate. Pediatrics 2008;121:419-432.

20 Tonks A, Parton J, Tonks AJ, Morris RHK, Finall A, Jones KP, Jackson SK: Surfactant phospholipid DPPC downregulates monocyte respiratory burst via modulation of PKC. Am J Physiol 2005;288:L1070-L1080.

21 Notter RH, Wang Z, Egan EA, Holm BA: Component specific surface and physiological activity in bovine-derived surfactants. Chem Phys Lipids 2002;114:21-34.

22 Walther FJ, Hernandez-Juviel J, Bruni R, Waring AJ: Spiking Survanta with synthetic surfactant peptides improves oxygenation in surfactant deficient mice. Am J Physiol 1997; 156:855-861.

23 Rudiger M, von Baehr A, Haupt R, Wauer RR, Rustow B: Preterm infants with high polyunsaturated fatty acid and plasmalogen content in tracheal aspirates develop bronchopulmonary dysplasia less often. Crit Care Med 2000;28:1572-1577.

24 Bloom BT, Kattwinkel J, Hall RT, Delmore PM, Egan EA, Trout JR, Malloy MH, Brown DR, Holzman IR, Coghill CH, Carlo WA, Pramanik AK, McCaffree MA, Toubas PL, Laudert S, Gratny LL, Weatherstone KB, Seguin JH, Willett LD, Gutcher GR, Mueller $\mathrm{DH}$, Topper WH: Comparison of Infasurf (calf lung surfactant extract) to Survanta (beractant) in the treatment and prevention of respiratory distress syndrome. Pediatrics 1997;100:31-38

25 Bloom BT, Clark RH: Comparison of Infasurf (calfactant) and Survanta (beractant) in the prevention and treatment of respiratory distress syndrome. Pediatrics 2005;116:392399.

26 Speer CP, Gefeller O, Groneck P, Laufkötter E, Roll C, Hanssler L, Harms K, Herting E, Boenisch H, Windeler J: Randomised clinical trial of two treatment regimens of natural surfactant preparations in neonatal respiratory distress syndrome. Arch Dis Child 1995; 72:F8-F13.

-27 Baroutis G, Kaleyias J, Liarou T, Papathoma E, Hatzistamatiou Z, Costalos C: Comparison of three treatment regimens of natural surfactant preparations in neonatal respiratory distress syndrome. Eur J Pediatr 2003; 162:476-480.
28 Ramanathan R, Rasmussen MR, Gerstmann DR, Finer N, Sekar K, North American Study Group: A randomized, multicenter masked comparison trial of poractant alfa (Curosurf) versus beractant (Survanta) in the treatment of respiratory distress syndrome in preterm infants. Am J Perinatol 2004;21: 109-119.

29 Halliday HL: History of surfactant from 1980. Biol Neonate 2005;87:317-322.

30 Malloy CA, Nicoski P, Muraskas JK: A randomized trial comparing beractant and poractant treatment in neonatal respiratory distress syndrome. Acta Paediatr 2005;94: 779-784

31 Gerdes JS, Seiberlich W, Sivieri EM, Marsh W, Varner DL, Turck CJ, York JM: An openlabel comparison of calfactant and poractant alfa administration traits and impact on neonatal intensive care unit resources. J Pediatr Pharmacol Ther 2006;11:92-100.

32 Marsh W, Smeeding J, York JM, Ramanathan R, Sekar K: A cost minimization comparison of two surfactants - beractant and poractant alfa - based upon prospectively designed, comparative clinical trials. J Pediatr Pharmacol Ther 2004;9:117-125.

33 Ramanathan R: Optimal ventilatory strategies and surfactant to protect the preterm lings. Neonatology 2008;93:302-308.

34 Clark RH, Auten RL, Peabody J: A comparison of the outcomes of neonates treated with two different natural surfactants. J Pediatr 2001;139:828-831.

35 Ramanathan R, Saunders WB, Lavin PT, Sekar KC, Ernst FR, Bhatia J: Mortality differences among preterm neonates treated with three different natural surfactants: analyses from a large national database. Acta Pediatr 2007;96(suppl 456):107.

36 Sekar KC, Bhatia J, Ernst FR, Saunders WB, Lavin PT, Ramanathan R: Resource use in preterm neonates with respiratory distress syndrome treated with one of three different natural surfactants: analyses using a large hospital discharge database. Acta Pediatr 2007;96(suppl 456):109. 